BISMA

(Bisnis dan Manajemen)
Volume 13, Issue 1, 2020, 69-80

ISSN 2549-7790 (Online)

DOI: 10.26740/bisma.v13n1.p69-80

https://journal.unesa.ac.id/index.php/bisma/index

\title{
The effect of job satisfaction, organizational communication, work environment, and work motivation on the church's employee performance
}

\author{
Jonathan Charmian Vivaldy ${ }^{1 *}$, Nagian Toni \\ ${ }^{1,2}$ Universitas Prima Indonesia, Indonesia
}

\begin{abstract}
This study aims to determine the effect of job satisfaction, organizational communication, work environment, and work motivation on the performance of big family of Indonesian Bethel Church Medan Plaza's employees both simultaneously and partially. The primary data is obtained by distributing questionnaires to all employees of the big family of Indonesian Bethel Church Medan Plaza. Data analysis was carried out by descriptive analysis, classical assumption test, and hypothesis test by multiple linear regression method. The result concludes that job satisfaction, organizational communication, work environment, and work motivation simultaneously affect employee performance. This research is expected to enrich the study of human resource management on the factors that influence performance in religious-based organizations that have not been widely studied in Indonesia.
\end{abstract}

Keywords: employee; job satisfaction; organizational communication; performance; work environment; work motivation

Received: February 4, 2020; Accepted: March 10, 2020; Published: October 31, 2020

*Corresponding author

Email: jonathanchvivaldy@gmail.com

\section{To cite this document:}

Vivaldy, J. C. \& Toni, N. (2020). The effect of job satisfaction, organizational communication, work environment, and work motivation on the church's employee performance. BISMA (Bisnis dan Manajemen), 13(1), 69-80. https://doi.org/10.26740/bisma.v13n1.69-80.

\section{INTRODUCTION}

In carrying out its duties, the church has an organizational structure whose members come from religious and professional circles. It has several divisions synergizing to carry out the church's duties, one of which is the big family of Indonesian Bethel Church, Medan Plaza. The big family of Indonesian Bethel Church Medan Plaza is one of the Indonesian Bethel Church branches, which operates in North Sumatera and surrounding areas in other provinces. Its central secretariat located in Medan City. To be a successful church in fulfilling all of its duties, it is essential to have good employee performance to analyze further the variables that affect church employee performance.

Previous research related to job satisfaction was conducted by Juniantara \& Riana (2015) to 130 account officers from 39 cooperatives. The result obtained from this study is job 
satisfaction affects employee performance. Therefore, it is believed that job satisfaction will also affect the big family of Indonesian Bethel Church Medan Plaza employee performance.

Previous research related to organizational communication was conducted by Enika (2016) to 56 employees of PT. IT, Samarinda. The result is that organizational communication affects employee performance. Hence, it is believed that organizational communication will also affect the employee performance of the big family of Indonesian Bethel Church Medan Plaza.

Meanwhile, previous research about the work environment was conducted by Kamif, Mukzam, \& Nurtjahjono (2016) on 61 employees of AGH, Malang. The result stated that the work environment affects employee performance. Therefore, it is believed that the work environment will also affect the employee performance of the big family of Indonesian Bethel Church Medan Plaza.

Work motivation on employee performance was studied by Sutrischastini \& Rianto (2015) to 162 employees of the Government secretariat office of Gunung Kidul Regency. The result obtained from this study is that work motivation affects the performance of employees of PT. KMA, Surabaya. Based on this research, work motivation will also affect the big family of Indonesian Bethel Church Medan Plaza employee performance.

Performance is the success achieved by employees in carrying out a work activity concerning their tasks (Rahadi, 2010; Lourenço \& Cesar, 2007). Meanwhile, Potale \& Uhing (2015) state that performance is the work of quality and quantity achieved by an employee in carrying out their duties under their responsibilities given to him. According to Robbins \& Judge (2015), performance is the form of work results that someone did. Employee performance is the work of quality and quantity achieved by an employee in carrying out their duties based on the responsibilities given to him (Mangkunegara, 2004).

Robbins \& Judge (2015) defines job satisfaction as an individual's general attitude towards his job. According to Mathis \& Jackson (2006), job satisfaction is what employees expect from work and what they reward based on their performance. Job satisfaction is an individual issue that there will be dynamics or changes at any time that must be anticipated to develop in the direction of negative things that are detrimental to the agency (Juniantara \& Riana, 2015). Job satisfaction is not becoming a strong motivational factor for achievement because employees who are satisfied at work may not necessarily increase their work performance. Therefore, the employee's job satisfaction needs serious attention from the managers of the organization (Marnis \& Priyono, 2008; Vlachos, Panagopoulos, \& Rapp, 2013).

Communication is delivering information (messages and ideas) from one party to another party. In general, communication is done verbally or non-verbally, which can be understood by the sender and receiver. There is no verbal language that can be understood by both, communication can still be done by gestures such as smiling, shaking the head, shrugging shoulders, which is called non-verbal communication (Waridah, 2016; Sielski, 1979).

Communication is the process of sending and receiving information or message between two or more people effectively, resulting in the meaning of a message can be understood (Firmansyah \& Syamsudin, 2016). Communication in organizations can occur in written or spoken words, gestures, or visual symbols that produce behaviour changes within the organization, between managers, employees, and associations involved in giving or 
The effect of job satisfaction, organizational communication, work environment, and work motivation on the church's employee performance

transferring communication. The result is the exchange of information and the delivery of meaning or the process of communication activities in the organization (Vardiansyah, 2004; Haythornthwaite, 1996).

Communication is a bridge that brings members together in a company (Johan \& Noor, 2013) Sometimes, the employee does not realize how important to smooth the communication. This generally occurs due to the high ego of someone who tends to direct communication and not listen to others' opinions.

According to Nitisemito (2008), the work environment exists around workers and can affect it in carrying out the work that has been entrusted. Meanwhile, according to Sedarmayanti (2009), the work environment is "everything that exists in the environment of workers both physical and psychological related to where a person works either as individuals or groups". The work environment is everything around the worker both inside and outside the office, including physical or not, that affect employees in carrying out the tasks they carry (Kamif, Mukzam, \& Nurtjahjono, 2016; Elsbach \& Bechky, 2007).

Motivation is an activator or impulse in humans that can lead to direct and organized behaviour (Darmawan, 2013; Forbes \& Dahl, 2010). According to Hasibuan (2013), work motivation is the driving force that creates the excitement of someone's work, so they want to work with all their efforts to achieve satisfaction. Moreover, Supardi \& Anwar (2004) mention work motivation is a state of being within a person that drives an individual desire to carry out certain activities to achieve goals. Gibson et. al. (2000) states that motivation is the force that drives an employee to generate and direct behaviour. Based on the introduction above, the purpose of this study is to find out the effect of job satisfaction, organizational communication, work environment, and work motivation on the performance of big family Indonesian Bethel Church Medan Plaza's employees both simultaneously and partially.

\section{Job Satisfaction and Employee Performance}

Robbins \& Judge (2015) found a strong correlation between job satisfaction and employee performance. They stated that when someone moves from the individual to the organizational level, they also support the satisfaction-performance relationship. When someone collects satisfaction and performance data for the organization as a whole, they find that organizations with a lot more employees who are more satisfied tend to be more effective than organizations that are more a little. Gibson et al. (2000) explicitly describe a reciprocal relationship between performance and job satisfaction. Meanwhile, job satisfaction causes an increase in concert to be more productive. On the other hand, job satisfaction can also occur due to performance or work performance to get satisfaction more productive. The result of the research was conducted by Baroroh (2013) on 100 employees of PT. HI shows that job satisfaction has a significant positive correlation with performance.

H1: Job satisfaction significantly influences employee performance.

\section{Organizational Communication and Employee Performance}

According to Armstrong \& Baron (1998), performance is the result of activities carried out to achieve company goals, and two factors affect the performance, which one is 
organizational communication. The result of research that conducted by Lenggawa (2018) on 100 members of the Indonesian National Student Movement shows that corporate communication has a positively significant correlation with performance, but Rodwell (1998) found that communication has a negative correlation with a performance which the analysis of the pattern of relationships indicates that while the direct relationship between communication and performance is negative.

$\mathrm{H} 2$ : Organizational communication significantly influences employee performance.

\section{Work Environment and Employee Performance}

According to Timpe (1993), performance is influenced by environmental factors where if the environment is good, then performance is also good and vice versa. Mardiana (2005) stated that a conducive work environment provides a sense of security and allows employees to work optimally. Lee \& Brand (2005) state that companies' work environment is expected to support employee performance. The research conducted by Wijaya \& Susanty (2017) on 39 employees of the Musi Banyuasin regency office's regional government shows that the work environment positively affects employee performance. Still, the research conducted by Suprihati (2014) on 50 employees of the Sari Jati company shows the result that the work environment harms employee performance.

H3: Work environment significantly influences employee performance.

\section{Work Motivation and Employee Performance}

According to Munandar (2001), work motivation has a relationship with work performance. Job performance is the result of the interaction between work motivation, abilities, and opportunities. When work motivation is low, work performance will be low even though the employee has good ability and has the opportunity. Hasibuan (2013) stated that motivation is needed to support activities that directly increase performance. Motivation is the empowerment of the driving force that creates the excitement of one's work. An employee is willing to cooperate, work effectively, and be integrated with all his efforts to achieve satisfaction (Chang \& Lee, 2007). The research conducted by Imlawal \& Winarningsih (2016) on 38 employees of the pool and the lounge shows that motivation has a significant positive effect on employee performance.

H4: Work motivation significantly influences employee performance.

\section{METHODS}

This research was conducted at the big family of Indonesian Bethel Church Medan Plaza Central Secretariat in Indonesian Bethel Church House of Sacrifice in Medan City, North Sumatera. Sampling used is a saturated sample in which all members of the population were sampled. In this study, the number of samples was 37 people. This research is descriptive research that describes the phenomena that exist, both natural phenomena and human-made phenomena.

The interval class uses in this study are: 1.00 to 1.80 that categorized into "very low"; intervals 1.81 to 2.60 is categorized into "low"; 2.61 to 3.40 is categorized into "moderate"; interval 3.41 to 4.20 is categorized into "high"; intervals of 4.21 to 5.00 is categorized into "very high". Meanwhile, the assessment indicator uses Likert Scale: "very agree" is given a 
The effect of job satisfaction, organizational communication, work environment, and work motivation on the church's employee performance

value for 5; "agree" is given value for 4, "neutral" is given a value for 3, "disagree" is given value for 2, and "very disagree" is given value for 1 .

Data analysis conducted in this research was in descriptive analysis, classical assumption test, and hypothesis test. In this study, the descriptive analysis consisted of analyzing each variable's level obtained through the average score on the questionnaire and the ranking analysis of each statement with the highest score and the lowest score. The classical assumption test in this study is the normality test, linearity test, and multicollinearity test.

Variables that cause multicollinearity can be seen from tolerance value smaller than 0.1 or a VIF value that greater than a value=10. A good regression model should be free from correlations between independent variables (Ghozali, 2011) and if the value of the Variance Inflation Factor (VIF) is not more than ten and the Tolerance (TOL) value is more than 0.1 .

Moreover. F-test is used to acknowledge all independent variables' simultaneous effects to the dependent variable, which F-count $<$ F-table, then $\mathrm{H}_{0}$ is accepted, and $\mathrm{H}_{1}$ is rejected and if $\mathrm{F}$-count $\geq \mathrm{F}$-table, then $\mathrm{H}_{0}$ is rejected and $\mathrm{H}_{1}$ is accepted. The t-test is used to acknowledge the partial effect of all independent variables on the dependent variable, which $t$-count $>t$-table or $\mathrm{t}$-count $<\mathrm{t}$-table, then $\mathrm{H}_{0}$ is rejected and $\mathrm{H}_{2}$ is accepted.

\section{RESULT AND DISCUSSION}

\section{Descriptive Analysis}

After obtaining a suitable questionnaire as a research instrument, the same questionnaire was distributed to 37 respondents. Data analysis was performed in the form of a classical assumption test and a hypothesis test. The descriptive statistic results that job satisfaction with an average score $=3.608$, organizational communication with average score $=0.892$, a work environment with average score $=3.732$, work motivation with average score $=3.722$, and employee performance with average score $=3.711$. Therefore, all variables are classified into high category. On the other word, job satisfaction, organizational communication, work environment, work motivation, and employee performance in big family of Indonesian Bethel Church Medan Plaza are not yet optimal and needs to be improved.

\section{Classical Assumption Test}

After the descriptive analysis has been done, the next is a classical assumption test consisting of a normality test, a multicollinearity test, and a heteroscedasticity test. The normality test result obtained for each variable are job satisfaction with $\mathrm{X}^{2}$ score $=4.2898$, organizational communication with $\mathrm{X}^{2}$ score $=1.2819$, a work environment with $\mathrm{X}^{2}$ score $=6.3779$, work motivation with $X^{2}$ score $=5.6648$, and employee performance with $X^{2}$ score $=6.7164$ which all $X^{2}$ score are smaller than $X_{(d f-4 ; 0.1)}^{2}=7.778$. It means that all variables can be declared normally distributed.

After the respondent's answer to all variable otherwise normal distribution, the next test is the multicollinearity test. Multicollinearity test results are $\mathrm{X} 1$ has a VIF value $=1.002, \mathrm{X} 2 \mathrm{has}$ a VIF value $=1.026, \mathrm{X} 3$ has a VIF value $=1.014$, and X4 has a VIF value $=1.141$. Based on the results, the value is known that VIF for each variable is in the range value of $0.1<\mathrm{VIF}<10$ so it is no symptoms of multilinear. 
The next test is the heteroscedasticity test. The heteroscedasticity test result is intercepted has $\mathrm{p}$-value $=0.9198, \mathrm{X} 1$ has $\mathrm{p}$-value $=0.1458, \mathrm{X} 2$ has $\mathrm{p}$-value $=0.5836, \mathrm{X} 3$ has $\mathrm{p}$-value $=0.5042$ and $\mathrm{X} 4$ has $\mathrm{p}$-count $=0.1439$ which all $\mathrm{p}$-value is higher than 0.05 which means it is no symptoms of heteroscedasticity.

\section{Hypothesis Test}

Hypothesis test consists of multiple linear regression analysis, coefficient of determination, F-test, and t-test. The result of multiple linear regression analyzes is presented in Table 1.

Table 1. Multiple Linear Regression Analyzes Results

\begin{tabular}{lc}
\hline \multicolumn{1}{c}{ Constant } & Coefficient \\
\hline Intercept & 37.385 \\
Constant X1 & 0.0448 \\
Constant X2 & -0.2501 \\
Constant X3 & -0.2087 \\
Constant X4 & 0.4201 \\
Multiple R & 0.4615 \\
\hline
\end{tabular}

Based on Table 1, there is a relationship between job satisfaction, organizational communication, work environment, and work motivation on employees performance of the big family of Indonesia Bethel Church Medan Plaza as formulation 1.

$\mathrm{Y}=37.3854+0.0448 \mathrm{X} 1-0.2501 \mathrm{X} 2-0.2087 \mathrm{X} 3+0.4201 \mathrm{X} 4$

Based on the above equation, it can be explained that job satisfaction variables affect employee performance by 0.0448 . This shows that the higher the level of job satisfaction, the higher the employee's performance. For every increase in the degree of job satisfaction by 1.00 , the degree of employee performance will increase by 0.0448 .

Organizational communication variables affect employee performance by -0.2501 . This shows that the higher the level of organizational communication, the lower the employee's performance. Each increase in job satisfaction by 1.00 will decrease the degree of employee performance by 0.2501 .

Work environment variables affect employee performance by -0.2087 . This shows that the higher the level of the work environment, the lower the employee's performance. Each increase in job satisfaction by 1.00 will decrease the degree of employee performance by 0.2087 .

The work motivation variable affects employee performance by 0.4201 . This shows that the higher the level of work motivation, the higher the employee's performance. Any increase in job satisfaction of 1.00 will increase the degree of employee performance by 0.4201 .

Meanwhile, Multiple $\mathrm{R}=0.4615$ which still in the interval of 0.400-0.599. Hence, it means that there is a moderate relationship between job satisfaction, organizational communication, work environment, and work motivation on employee performance.

The coefficient of determination (Adjusted $\mathrm{R}^{2}$ ) calculation results $=0.1146$, which is still inside $0<\mathrm{R}^{2}<1$ range. This shows that the model used is suitable for explaining the dependent variable's proportion through free variables. F-table for $\mathrm{df}=32, \alpha=0.10$ is 2.13 . Based on the calculation results obtained the calculated value is 2.1646 which show that $\mathrm{F}$-count $>\mathrm{F}$-table. 
The effect of job satisfaction, organizational communication, work environment, and work motivation on the church's employee performance

Therefore, $\mathrm{H}_{0}$ is rejected and $\mathrm{H} 1$ is accepted, which means job satisfaction, organizational communication, work environment, and work motivation have a simultaneous effect on the big family of Indonesian Bethel Church Medan Plaza.

The t-test results are job satisfaction on performance has a $\mathrm{t}$-count $=0.2203$; organizational communication on performance has a t-count=-14819; work environment on performance has a $\mathrm{t}$-count $=-12406$; work motivation on performance has $\mathrm{t}$-count $=2.5480$. The $\mathrm{t}$-table value for $\mathrm{df}=32$ and $\alpha=0.50 / 2=0.25$ is 0.68223 .

Based on the t-test results above, the $\mathrm{t}$-count for the job satisfaction variable is equal to 0.2203. Because $t$-count $>t$-table, it is stated that $\mathrm{H}_{0}$ is rejected, and $\mathrm{H}_{2}$ is accepted. It explains that job satisfaction partially affects the big family of Indonesian Bethel Church Medan Plaza's employee performance.

The $t$-count for the organizational communication variable is equal to -1.4819 . Because $\mathrm{t}$-count<t-table, $\mathrm{H} 0$ is rejected, and $\mathrm{H} 3$ is accepted where organizational communication partially affects employee performance of big family of Indonesian Bethel Church Medan Plaza.

The $\mathrm{t}$-count of the work environment variable is -1.24056 . Because $\mathrm{t}$-count $<\mathrm{t}$-table, $\mathrm{H}_{0}$ is rejected and $\mathrm{H}_{4}$ is accepted by the work environment partially affects the employee performance of big family of Indonesian Bethel Church Medan Plaza. The t-count of the work motivation variable is 2.5480 . Because $\mathrm{t}$-count $<\mathrm{t}$-table, $\mathrm{H} 0$ is rejected and $\mathrm{H} 4$ is accepted. It means work environment partially affects the employee performance of big family of Indonesian Bethel Church Medan Plaza.

\section{Discussion}

Job satisfaction has a positive effect on employee performance. This is supported by previous research conducted by Khoir \& Rosida (2016) and Soomro, Breitenecker, \& Shah (2018). Organizational communication influence employee performance. This result supports Rodwell (1998), which states that communication is negatively related to employee performance and research conducted by Mamonto, et al. (2016). It also includes interpersonal communication harming employee performance. Meanwhile, the work environment partially affects the employee performance in big family of Indonesian Bethel Church Medan, where the results of this study meet with the previous hypothesis.

Work environment influences employee performance. This supports Suprihati (2014) and Pawirosumarto, Sarjana, \& Gunawan (2017) research. In the other side, work motivation partially affects employee performance in big family of Indonesia Bethel Church Medan Plaza. Work motivation has a positive effect on employee performance. This is supported by previous research conducted by Mandasari (2015) and Orpen (1997) where the result is that work motivation has a positive effect on employee performance.

This study proves that job satisfaction, organizational communication, work environment, and work motivation simultaneously affect the performance of employees of the big family of Indonesian Bethel Church Medan Plaza. Job satisfaction and work motivation variables contribute positively to the simultaneous effect, but organizational communication and work environment contribute negatively to the simultaneous effect. It means that big family 
of Indonesian Bethel Church Medan Plaza needs to optimize employee performance by increasing job satisfaction and work motivation of employee performance. This organization also needs to improve its organizational communication and work environment because it will positively influence the big family of Indonesian Bethel Church Medan Plaza employee performance.

This result also confirms Juniantara \& Riana (2015) study about the effect of job satisfaction on employee performance, Enika (2016) study on the impact of organizational communication on employee performance, Kamif, Mukzam, \& Nurtjahjono (2016) study about the effect of work environment on employee performance, Sutrischastini \& Rianto (2015) on the impact of work motivation on employees' performance.

\section{CONCLUSION}

Based on the study results, job satisfaction, organizational communication, work environment, and work motivation simultaneously affect the employee performance of big family of Indonesian Bethel Church Medan Plaza. This study recommends the big family of Indonesian Bethel Church Medan Plaza to provide challenges with an appropriate portion of each assignment given to its employees. The employee will have higher satisfaction if they get organization supports in terms of health and security improvement. Hence, church organizations need to pay attention to their employees' job satisfaction and work motivation by conducting internal research so that job satisfaction and effective work motivation factors can be identified and considered in any decisions related to improving human resource performance. The limitations of this research is it was conducted only in a church, so it is not easy to generalized. For further research, this study suggests examining different influential variables on church's employee performance such as religiousity.

\section{REFERENCES}

Armstrong, M. \& Baron, A. (1998). Performance Management - The New Realities. London: Institute of Personnel and Development.

Baroroh, S. (2013). Hubungan Antara Kepuasan Kerja Dengan Kinerja Karyawan. Publication Manuscript, Universitas Muhammadiyah Surakarta. http://eprints.ums.ac.id/id/eprint/26721.

Chang, S. \& Lee, M. (2007). A study on relationship among leadership, organizational culture, the operation of learning organization and employees' job satisfaction. The Learning Organization, 14(2), 155-185. https://doi.org/10.1108/09696470710727014.

Darmawan. (2013). Metode Penelitian Kuantitatif. Bandung: Remaja Rosdakarya.

Djaali. (2008). Skala Likert. Jakarta: Pustaka Utama.

Elsbach, K. D., \& Bechky, B. A. (2007). It's More Than a Desk: Working Smarter through Leveraged Office Design. California Management Review, 49(2), 80-101. https://doi.org/10.2307/41166384. 
The effect of job satisfaction, organizational communication, work environment, and work motivation on the church's employee performance

Enika. (2016). Pengaruh Komunikasi Organisasi dan Motivasi terhadap Kinerja Karyawan PT. Inti Tractors Samarinda. E-Jurnal Ilmu Komunikasi, 4(2). https://ejournal.ilkom.fisipunmul.ac.id/site/?p=2420.

Firmansyah, H. \& Syamsudin, A. (2016). Organisasi dan Manajemen Bisnis. Yogyakarta: Ombak.

Forbes, E. E. \& Dahl, R. E. (2010). Pubertal development and behavior: Hormonal activation of social and motivational tendencies. Brain and Cognition, 72(1), 66-72. https://doi.org/10.1016/j.bandc.2009.10.007.

Gibson, J. L., Ivancevich, J. M., \& Donelly, J. H. (2000). Organisasi: Perilaku, Struktur, 5th Edition. Jakarta: Binarupa Aksara.

Ghozali, I. (2011). Aplikasi Analisis Multivariate Dengan Program SPSS. Semarang: Badan Penerbit Universitas Diponegoro.

Hasibuan, M. S. P. (2013). Manajemen Sumber Daya Manusia Edisi Revisi. Bandung: PT. Bumi Aksara.

Haythornthwaite, C. (1996). Social network analysis: An approach and technique for the study of information Exchange. Library \& Information Science Research, 18(4), 323-342. https://doi.org/10.1016/S0740-8188(96)90003-1.

Imlawal, T. \& Winarningsih. (2016). Pengaruh Gaji dan Motivasi Kerja terhadap Kinerja Karyawan Players Pool N Lounge. Jurnal Ilmu dan Riset Manajemen, 5(2), 1-16.

Johan, M. R. M. \& Noor, N. A. Z. M. (2013). The Role of Corporate Communication in Building Organization's Corporate Reputation: An Exploratory Analysis. Interdisciplinary Journal of Contemporary Research in Business. 4(12), 1230-1240. https://journal-archieves31.webs.com/1230-1240.pdf.

Juniantara, I. W. \& Riana, I. G. (2015). Pengaruh Motivasi Kerja dan Kepuasan Kerja terhadap Kinerja Karyawan Koperasi di Denpasar. E-Jurnal Ekonomi dan Bisnis Universitas Udayana, 4(9), 611-628. https://ojs.unud.ac.id/index.php/EEB/article/view/12082/11841.

Kamif, M., Mukzam, M. D., \& Nurtjahjono, G. E. (2016). Pengaruh Lingkungan Kerja terhadap Kinerja (Studi pada Karyawan Hotel Aria Gajayana Malang). Jurnal Administrasi Bisnis, 38(1), 89-96. http://administrasibisnis.studentjournal.ub.ac.id/index.php/jab/article/view/1486/1865.

Khoir, A. N. \& Rosidah. (2016). Pengaruh Motivasi Kerja, Kepuasan Kerja dan Lingkungan Kerja terhadap Kinerja Pegawai di Pusat Sains dan Teknologi Akselerator Badan Tenaga 
Nuklir Nasional Yogyakarta. Jurnal Pendidikan Administrasi Perkantoran, 5(6), 614622.

Lourenço, U. C. \& Cesar A. S. F. (2007). Staff development and performance appraisal in a Brazilian research centre. European Journal of Innovation Management, 10 (1), 109-125. https://doi.org/10.1108/14601060710720573

Lee, S. Y. \& Brand, G. L. (2005). Effects of Control over Office Workspace on Perceptions of the Work Environment and Work Outcomes. Journal of Environmental Psychology, 25, 323-333.

Lenggawa, V. A. (2018). Hubungan Komunikasi Organisasi dengan Kinerja Anggota Gerakan Mahasiswa Nasional Indonesia (Studi Korelasional Mengenai Hubungan Komunikasi dengan Kinerja Anggota Gerakan Mahasiswa Nasional Indonesia Dewan Pimpinan Cabang Bandung). Conference on Dynamic Media, Communications, and Culture, 1, 6187.

Mamonto, W. F., Nelwan, O. S., \& Sendow, G. M. (2016). Pengaruh Kepemimpinan Transformasional, Komunikasi Interpersonal dan Kepuasan Kerja terhadap Kinerja Karyawan (Studi Kasus Pada PT. Sulut Makmur Perkasa Kotamobagu). Jurnal EMBA. 4(4), 1249-1258.

Mandasari, W. (2015). Upaya Peningkatan Kinerja Karyawan Operasional melalui Motivasi Kerja (Studi Kasus pada Lembaga Penyiaran Publik RRI Semarang). Skripsi, Universitas Dian Nuswantoro, Semarang, Indonesia. Retrieved 6 March, 2020 from http://eprints.dinus.ac.id/id/eprint/17230.

Mangkunegara, A. A. A. P. (2004). Manajemen Sumber Daya Manusia Perusahaan. Bandung: PT. Remaja Rosda Karya.

Mardiana. (2005). Manajemen Produksi. Jakarta: Badan Penerbit IPWI.

Marnis \& Priyono. (2008). Manajemen Sumber Daya Manusia. Sidoarjo: Zifatama Publisher.

Mathis, R. L. \& Jackson, J. H. (2006). Human Resource Management. Jakarta: Salemba Empat.

Munandar, A. S. (2001). Psikologi Industri Dan Organisasi. Jakarta: Universitas Indonesia Press.

Nitisemito, A. S. (2008). Manajemen Personalia. Jakarta : PT. Ghalia Indonesia.

Nduru, R. E., Situmorang, M., \& Tarigan, G. (2014). Analisa Faktor-Faktor yang Mempengaruhi Hasil Produksi Padi di Deli Serdang. Jurnal Saintia Matematika, 2(1), 71-83.

Nurgiyantoro, B., Gunawan, \& Marzuki (2004). Statistik Terapan Untuk Penelitian Ilmu-Ilmu Sosial. Yogyakarta: Gadjah Mada University Press. 
The effect of job satisfaction, organizational communication, work environment, and work motivation on the church's employee performance

Orpen, C. (1997). The effects of formal mentoring on employee work motivation, organizational commitment and job performance. The Learning Organization, 4(2), 5360. https://doi.org/10.1108/09696479710160906.

Pawirosumarto, S., Sarjana, P. K., \& Gunawan, R. (2017). The effect of work environment, leadership style, and organizational culture towards job satisfaction and its implication towards employee performance in Parador Hotels and Resorts, Indonesia. International Journal of Law and Management, 59(6), 1337-1358. https://doi.org/10.1108/IJLMA-102016-0085.

Potale, R. \& Uhing, Y. (2015). Pengaruh Kompensasi dan Stres Kerja terhadap Kepuasan Kerja Karyawan pada PT. Bank Sulut Cabang Utama Menado, Universitas Sam Ratulangi $\begin{array}{llll}\text { Manado. Jurnal 63-73. } & \text { 3(1), }\end{array}$ https://ejournal.unsrat.ac.id/index.php/emba/article/view/6567.

Priyatno. (2010). 5 Jam Belajar Olah Data dengan SPSS 19. Yogyakarta: Andi.

Rahadi. (2010). Manajemen Kinerja Sumber Daya Manusia. Malang: Tunggal Mandiri Publishing.

Robbins, S. P. \& Judge, T. A. (2015). Perilaku Organisasi, 16th Edition. Jakarta: Salemba Empat.

Rodwell, J. J., Kienzle, R., \& Shadur, M. A. (1998). The Relationship Among Work-Related Perceptions, Employee Attitudes, and Employee Performance: The Integral Role of Communications. Human Resource Management Journal, 37(3), 277-293. https://doi.org/10.1002/(SICI)1099-050X(199823/24)37:3/4\%3C277::AIDHRM9\%3E3.0.CO;2-E.

Rahmawanti, N. P., Swasto, B., \& Prasetya, A. (2014). Pengaruh Lingkungan kerja terhadap Kinerja Karyawan (Studi pada Karyawan Kantor Pelayanan Pajak Pratama Malang Utara. Jurnal Administrasi Bisnis, 8(2), 1-9.

Santoso, S. (2001). Mengolah Data Statistik Secara Profesional. Jakarta: PT. Alex Media Komputindo.

Sedarmayanti. (2009). Pengembangan Kepribadian Pegawai. Bandung: Mandar Maju.

Sielski, L. M. (1979). Understanding Body Language. Journal of Counseling \& Development, 57(5), 238-242. https://doi.org/10.1002/j.2164-4918.1979.tb05155.x.

Soomro, A. A., Breitenecker, R..J., \& Shah, S. A. M. (2018). Relation of work-life balance, work-family conflict, and family-work conflict with the employee performancemoderating role of job satisfaction. South Asian Journal of Business Studies, 7(1), 129146. https://doi.org/10.1108/SAJBS-02-2017-0018. 
Sugiyono. (2012). Memahami Penelitian Kualitatif. Bandung: Alfabeta.

Sukmadinata. (2006). Metode Penelitian Kualitatif. Bandung: Graha Aksara.

Supardi \& Anwar, B. (2004). Manajemen dan Motivasi. Jakarta: Balai Aksara.

Suprihati. (2014). Analisis Faktor-faktor yang Mempengaruhi Kinerja Karyawan Perusahaan Sari Jati di Sragen. Jurnal Paradigma, 12(1), 93-112.

Sutrischastini, A. \& Riyanto, A. (2015). Pengaruh Motivasi Kerja terhadap Kinerja Pegawai Kantor Sekretariat Daerah Kabupaten Gunung Kidul. Jurnal Kajian Bisnis, 23(2), 121137. http://jurnal.stieww.ac.id/index.php/jkb/article/view/164.

Timpe, A. D. (1993). Kinerja. Jakarta: PT. Gramedia.

Vardiansyah, D. (2004). Pengantar Ilmu Komunikasi. Bogor: Ghalia Indonesia.

Vlachos, P. A., Panagopoulos, N. G. \& Rapp, A. A. (2013). Feeling Good by Doing Good: Employee CSR-Induced Attributions, Job Satisfaction, and the Role of Charismatic Leadership. Journal of Business Ethics, 118, 577-588. https://doi.org/10.1007/s10551012-1590-1.

Waridah. (2016). Berkomunikasi dengan Berbahasa Yang Efektif dapat Meningkatkan Kinerja. Jurnal Simbolika, 231-239. http://ojs.uma.ac.id/index.php/simbolika/article/view/1036.

Widarjono. (2013). Ekonometrika: Pengantar dan Aplikasinya. Jakarta: Ekonosia.

Wijaya, H. \& Susanty, E. (2017). Pengaruh Lingkungan Kerja Terhadap Kinerja Pegawai Pada Instansi Pemerintah Daerah Kabupaten Musi Banyuasin (Studi Kasus Dinas Pertambangan and Energi Kabupaten Musi Banyuasin). Jurnal Ecoment Global: Kajian $\begin{array}{llll}\text { Bisnis dan } & \text { Manajemen, } & \text { 2(1), }\end{array}$ http://ejournal.uigm.ac.id/index.php/EG/article/view/213. 